\title{
Green cardamom increases Sirtuin-1 and reduces inflammation in overweight or obese patients with non-alcoholic fatty liver disease: a double-blind randomized placebo-controlled clinical trial
}

Milad Daneshi-Maskooni ${ }^{1}$, Seyed Ali Keshavarz ${ }^{2^{*}}$, Mostafa Qorbani ${ }^{3}$, Siavash Mansouri ${ }^{4}$, Seyed Moayed Alavian ${ }^{5}$, Mahtab Badri-Fariman ${ }^{1}$, Seyed Ali Jazayeri-Tehrani ${ }^{2}$ and Gity Sotoudeh ${ }^{{ }^{*}}$

\begin{abstract}
Background: Non-alcoholic fatty liver disease (NAFLD) is the hepatic component of metabolic syndrome. Despite the beneficial health effects of cardamom on dyslipidemia, hepatomegaly, and fasting hyperglycemia, no previous human study has been conducted on the efficacy of cardamom in NAFLD. The aim of this study was to assess the effects of green cardamom (GC) on serum Sirtuin-1 (Sirt1), inflammatory factors, and liver enzymes in overweight or obese NAFLD patients.
\end{abstract}

Methods: The recruitment of subjects was conducted at the polyclinic of the central hospital of National Iranian Oil Company (NIOC), Tehran. Eighty-seven patients who participated were divided randomly into two groups according to the ultrasonography and eligibility criteria as cardamom $(n=43)$ or placebo $(n=44)$. The intervention involves taking two $500 \mathrm{mg}$ capsules three times per day with meals for 3 months. General characteristics, dietary intake and physical activity status, weight and height were determined. In addition, serum Sirt1, tumor necrosis factor-alpha (TNF-a), high sensitive c-reactive protein (hs-CRP), interleukin-6 (IL-6), alanine transaminase (ALT), and aspartate transaminase (AST) were measured. The degree of fatty liver was determined at beginning and end of the study.

Results: In comparison with placebo, GC significantly increased Sirt1 and decreased hs-CRP, TNF-a, IL-6, ALT, and the degree of fatty liver $(P<0.05)$. The differences in weight, BMI, and AST were not significant $(P>0.05)$.

Conclusion: GC supplementation could improve some biomarkers related to fatty liver including inflammation, ALT, and Sirt1 in overweight/obese NAFLD patients. Further trials on cardamom's potential are suggested.

Trial registration: Iranian Registry of Clinical Trials, IRCT2015121317254N4. Registered 27/12/2015.

Keywords: Non-alcoholic fatty liver disease, Green cardamom, Overweight or obesity, Sirtuin-1, Inflammatory factors

\footnotetext{
* Correspondence: s_akeshavarz@yahoo.com; gsotodeh@tums.ac.ir

${ }^{2}$ Department of Clinical Nutrition, School of Nutritional Sciences and

Dietetics, Tehran University of Medical Sciences, Tehran, Iran

${ }^{1}$ Department of Community Nutrition, School of Nutritional Sciences and

Dietetics, Tehran University of Medical Sciences, No.44, Hojjatdoust Alley,

Naderi Ave, Keshavarz Blvd, Tehran 1416643931, Iran

Full list of author information is available at the end of the article
}

(c) The Author(s). 2018 Open Access This article is distributed under the terms of the Creative Commons Attribution 4.0 International License (http://creativecommons.org/licenses/by/4.0/), which permits unrestricted use, distribution, and 


\section{Background}

Non-alcoholic fatty liver disease (NAFLD), as a triglyceride accumulation of more than $5 \%$ in hepatocytes [1], is emerging presently [2]. The prevalence is $25.2 \%$ globally [3], 65$85 \%$ in obese and $15-20 \%$ in non-obese adults [4, 5], and between 20 and 40\% in Iranian adults [6, 7]. NAFLD ranges from simple hepatic steatosis to non-alcoholic steatohepatitis (NASH) and sometimes cirrhosis. Obesity, impaired blood glucose, hypertension, and hyperlipidemia as characteristics of metabolic syndrome [8, 9], family history, age, severe weight loss, malnutrition, certain medicines or diseases [10], and enteric microbiota [11] are some risk factors of NAFLD. In simple words, NAFLD is the hepatic component of metabolic syndrome [12]. The inflammatory cytokines, oxidative stress and subsequently insulin resistance may play a role in the pathology of this disease [13, 14]. There is a direct correlation between insulin resistance and liver fat content. The activators of nuclear factor $\mathrm{kB}$ $(\mathrm{NF}-\mathrm{kB})$ including TNF- $\alpha$, increase the inflammatory cytokines that can subsequently impair insulin sensitivity [4].

The silent information regulators proteins (sirtuins) have either mono-ADP-ribosyltransferase or deacylase activity, including deacetylase, desuccinylase, demalonylase, demyristoylase and depalmitoylase activity. Of the seven identified sirtuins -Sirt1 to Sirt7- in mammals, Sirt1 has been mostly studied. The activation of Sirt1 has different health benefits $[15,16]$. Sirt1 as a histone deacetylase-III in humans [17], decreases oxidative stress by activating antioxidant enzymes including superoxide dismutase (SOD) and catalase [18]. It plays important roles in insulin secretion, lipid/glucose/energy metabolism, insulin resistance, inflammatory process, cardiovascular, kidney, and NAFLD diseases [19], mitochondrial and physiological function, and weight reduction $[15,16]$. Also, Sirt1 can increase PPAR- $\gamma$ coactivator-1 alpha $(\mathrm{PGC}-1 \alpha)$ that suppresses NF-kB $[15,17,20]$. According to some evidence, Sirt1 is downregulated in the liver of NAFLD patients [21].

The dietary polyphenols play important roles as anti-oxidant and anti-inflammatory compounds [22]. GC as a spice contains multiple polyphenols including flavone (luteolin), flavonols (quercetin and kaempferol), and anthocyanidin (pelargonidin) [23] that are NF-kB suppressors [23-26]. The flavonoids and isoflavones (quercetin, resveratrol, and kaempferol) activate PGC- $1 \alpha$ $[27,28]$ and accordingly, GC may affect insulin sensitivity and hepatic steatosis by suppressing oxidative stress and inflammation [29].

Lifestyle changes such as being physically active and losing weight gradually are the common treatment of NAFLD [30, 31]. Because of the poorly characterized pathogenesis of NAFLD and the controversial treatment of it, new therapeutic plans may be effective for the prevention and treatment of NAFLD [32]. The long-term keeping of weight loss is a challenge [33], and so, the new approaches such as change of dietary components may be helpful [34, 35-37]. GC has some beneficial health effects including antihypertensive, antioxidant, fibrinolysis enhancement, gastroprotective, antispasmodic, antibacterial [38], anti-inflammatory, anti-food toxins, anticarcinogenic, carminative, heart improvement, expectorant, diuretic [39], and antiplatelet aggregation [40]. The 1,8-cineole and alpha-terpinyl acetate are the most common agents of cardamom volatile oil. The reported effects for 1,8-cineole as the most extensively studied agent include the increase of apoptosis, the suppressing of prostaglandins, cytokines, nitric oxide, leukotrienes, interleukin-1 beta (IL-1 $\beta$ ), TNF- $\alpha$, inducible-nitric oxide synthase (iNOS), and cyclooxygenase-2 (COX-2), decrease of liver necrosis, vessels relaxation, the muscarinic receptors blocking, and anticholinergic effect [41].

It was supposed that anti-inflammatory, antioxidant, hypolipidemic, and antibacterial effects of GC may improve NAFLD. Due to important and beneficial roles of Sirt1 in different metabolic pathways involved in the metabolic disorders especially fatty liver, many studies have assessed the activation of Sirt1 for effectively preventing the progress of the fatty liver disease [42, 43]. The stimulating Sirt1 secretion in overweight or obese NAFLD patients by GC needs to be investigated. The levels of serum Sirt1 and the GC efficacy in overweight or obese NAFLD patients have not been previously studied. This trial was designed to assess the effect of GC on serum levels of Sirt1, inflammatory factors, and liver enzymes in overweight or obese NAFLD patients.

\section{Methods}

\section{Study design and subjects}

This study was designed as a double-blind randomized placebo-controlled clinical trial, approved by the ethics committee of Tehran University of Medical Sciences as IR.TUMS.REC.1394.791, and registered as IRCT2015121317254N4 on 27/12/2015. The participants were overweight or obese NAFLD patients referring to the sonography section of NIOC central hospital of Tehran. Our study lasted from 8 May 2016 until 17 September 2017.

Inclusion criteria were having NAFLD by ultrasonography, $30-60$ years old and $25 \leq \mathrm{BMI}<35 \mathrm{~kg} / \mathrm{m}^{2}$. Exclusion criteria were history of alcohol usage during the past 12 months, inability to cooperate, conditions influencing the liver, secondary NAFLD, disability, uncontrolled hypertension (>140/90 $\mathrm{mmHg}$ ), pregnancy or lactation, professional athlete, intake of ursodeoxycholic acid, antihypertensive, statins, probiotics, drugs interacting with cardamom, and antioxidant and multivitamin-mineral supplements during the past 3 months, weight loss for the 
past 3 months, and taking less than $90 \%$ of the study's supplements [35-37].

\section{Randomization and intervention}

The block randomization method was used to divide patients into two groups, by an assistant (cardamom $[n$ $=43]$ or placebo $[n=44]$ ). The stratified randomization was used for controlling age (30-45 and 46-60 yrs) and gender. The ratio of groups was 1:1. After randomization and before the commencement of the study, 3 subjects from GC group and 2 subjects from placebo group declined to participate (Fig. 1).

Both the subjects and investigators were blinded to the intervention allocation. GC was supplied by Samex agency, India. The GC and placebo capsules were similar in shape, size, and color and were prepared by the Traditional Medicine Research Center (TMRC), Iran University of Medical Sciences, Tehran, Iran. The capsules contained $0.5 \mathrm{~g}$ of whole GC or toast flour. Before the intervention, the placebo capsules were placed near the cardamom capsules weekly to have their smell. This absorbed amount of cardamom volatile oil by the placebo capsules is very negligible to affect health parameters. The blinding of supplements for patients and investigators was done through packaging as $\mathrm{A}$ and $\mathrm{B}$ packs by TMRC. The dose of GC supplement was selected as $3 \mathrm{~g} /$ day $[38,44]$ i.e. 2 capsules with each meal. Similarly, dose of the toast flour as placebo supplement was $3 \mathrm{~g} /$ day. The distribution of supplements was once a month and processes such as consumed capsules, potential complications, and the returned packages were checked monthly and by telephone weekly. The recommendations for lifestyle changes were given by an expert dietitian (MDM) placed in the hospital. The process of conducting the trial was checked by an assistant frequently and independently.

The characteristic of GC was Elettaria cardamomum (L.) Maton, Family: Zingiberaceae, PMP-669. The whole GC was analyzed by The Institute of Medicinal Plants, Shahid Beheshti University of Medical Sciences, Tehran. The essential oil contents of GC by the gas chromatography-mass spectrometry (GC-MS) were $41 \% \alpha$-terpinyl acetate and $30 \%$ 1,8-cineole. The content of total phenolic acid by high-performance liquid chromatography (HPLC) based on standard gallic acid was $10.53 \pm 0.18 \mu \mathrm{g}$ gallic acid equivalent/mg dry extract. Also, the content of total flavonoid by maceration method based on standard quercetin was 4.143 $\pm 1.865 \mu \mathrm{g}$ quercetin/mg dry extract.

\section{Assessments and measurements General characteristics, dietary intakes, and physical activity}

After identifying NAFLD patients, the eligibility criteria were checked, the details and benefits of the study were clarified, and informed consent was obtained by the principal investigator. The general questionnaire, 24-h

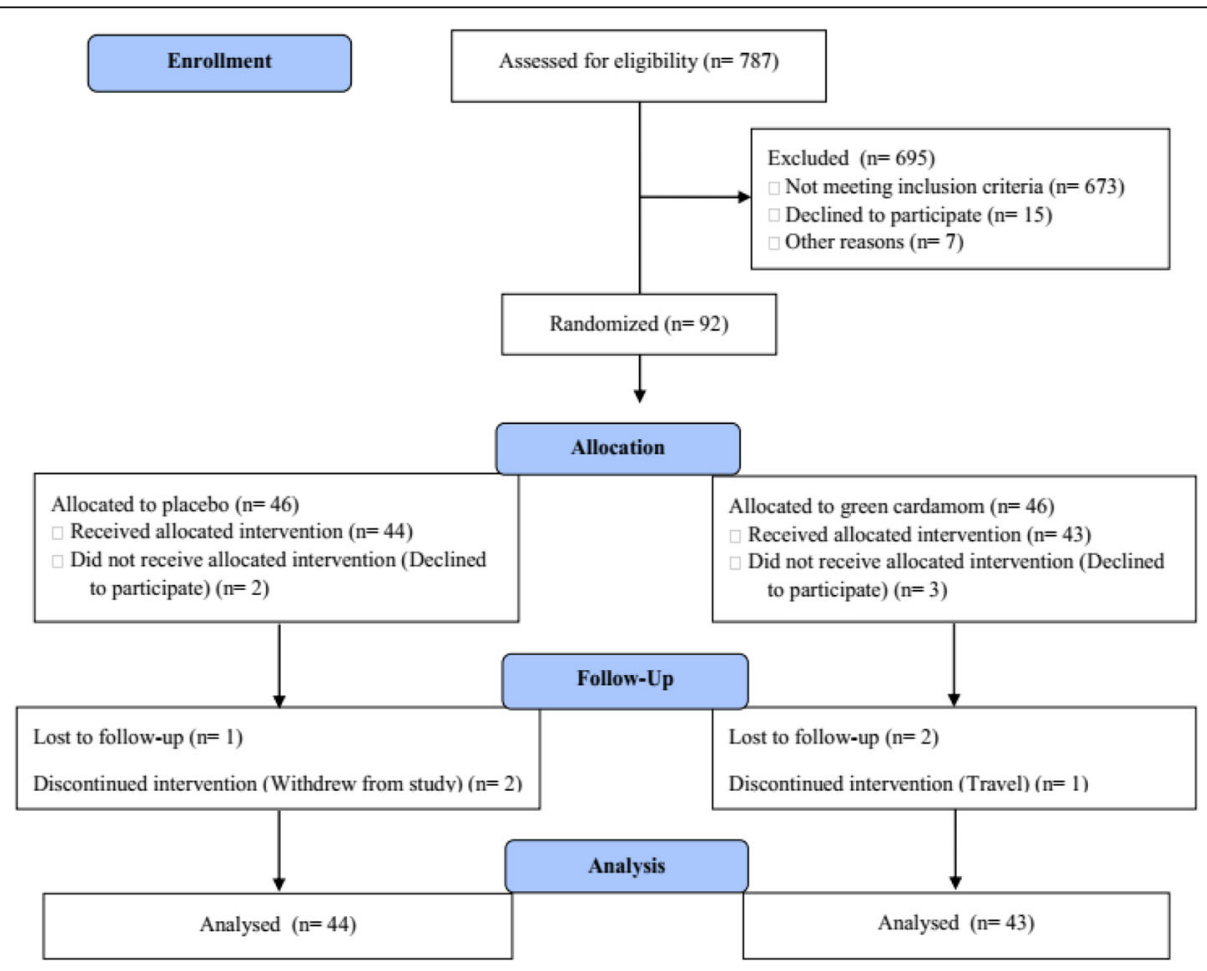

Fig. 1 Flow diagram of the study participants 
food recall (at the beginning, middle, and end), and short-form IPAQ (SF-IPAQ) questionnaire (at the beginning and end) were interviewly completed. The lifestyle recommendations [34] which include 5\% weight loss [45] and increasing moderate-intensity aerobic physical activity at least 3 times/week for 30-45 min [46] were advised at the beginning. The lifestyle changes which include being physically active and losing weight gradually are the common treatment of NAFLD [30, 31]. Therefore, the patients were advised to adopt these lifestyle changes to observe the medical ethics. These pieces of advice were equally presented to the all participants.

The values from 24-h food recall (valid in Iran [47]) were converted to gram per day [48]. The dietary status was determined using the Nutritionist 4 software [47].

The levels of physical activity were low $(<600$ MET-minutes/week), moderate $(600$ to $<1500$ MET-minutes/week), and high ( $\geq 1500$ MET-minutes/ week) [49]. The SF-IPAQ questionnaire had been validated in Iran $[50,51]$.

\section{Anthropometrics}

Weight (at the beginning and end) and height (at the beginning) were assessed using a digital scale and stadiometer (Seca ${ }^{\circ}$ Germany, Model: 755 1,021,994). Body mass index (BMI) was calculated by dividing the weight in kilograms by squared height in meters.

\section{Sonography and serum factors}

At the beginning and end of the study, the ultrasonography of liver was done after $12 \mathrm{~h}$ fasting state, by just one radiologist to reduce human error differences.

The $10 \mathrm{ml}$ blood (at the beginning and end) collected from the peripheral vein after 12 - $h$ fasting during the night was centrifuged for $20 \mathrm{~min}(3000 \mathrm{~g})$ and serum was frozen and stored at $-80{ }^{\circ} \mathrm{C}$ for analysis. The lab tasks (blood taking, storage, and tests) were done at the hospital.

Serum IL-6, TNF- $\alpha$, and Sirt1 were determined using the ELISA kits by Shanghai Crystal Day Biotech Co. $L_{t d}{ }^{\circ}$; Intra-assay $C V<8 \%$, Inter-assay $C V<10 \%$ and sandwich ELISA by an automatic device (Elisys Uno

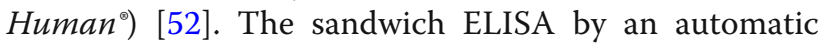
device (Elisys Uno Human ${ }^{\circ}$ ) for hs-CRP was done using ELISA kit by Diagnostics Biochem Canada (DBC) Inc, REF: CAN-CRP-4360, Version 5.0; Intra-assay $C V \leq 15.2 \%$, Inter-assay $C V \leq 9.9 \%$. The serum levels of ALT and AST were measured using Hitachi analyzer device $\left(q 17^{\circ}\right)$ and the specific kits as Bionik, Liquid Stable, NADH. Kinetic UV.IFCC, Intra-assay $C V \leq 4.27 \%$, Inter-assay $C V \leq 4.68 \%$ and Bionik, Liquid Stable, NADH. Kinetic UV.Liquid, Intra-assay $C V \leq 3.02 \%$, Inter-assay $C V \leq 3.00 \%$, respectively.

\section{The sample size}

The "two mean comparison formula" was used to calculate the sample size. In the previous study of the effects of cardamom on lipids, errors I and II, the mean difference of triglyceride (TG) between the groups, and the standard deviation of each group were 0.05 and 0.2 , $5 \mathrm{mg} / \mathrm{dl}$, and $8 \mathrm{mg} / \mathrm{dl}$, respectively [44]. In all, 46 subjects were considered for both groups (GC and placebo) with a prediction of $15 \%$ sample drop.

\section{Data analysis and accessibility}

The entry, security, coding, and storage of data were considered. The analysis was done by modified-intention to treat $(\mathrm{m}$-ITT). The ITT population included all the randomized participants who received the allocated intervention. The missing data were imputed by using regression imputation method. The Kolmogorov-Smirnov test was used to determine normality of continuous variables. Chi-square, Fisher exact test, and t-test or Mann-Whitney test were used to assessed categorical and continuous baseline characteristics, respectively. Time effects and time $\times$ treatment interaction effects on all dependent variables were determined using two way repeated measures analysis of variance (TWRM-ANOVA). TWRM-ANOVA was adjusted for dietary intake of vitamin $\mathrm{E}$ and B6. The measurements were reported with $95 \%$ confidence interval $(\mathrm{CI})$ and a $P$-value $<0.05$ was considered as statistically significant. The Statistical Package for Social Sciences, version 16 (SPSS Inc., Chicago, IL, USA) and STATA $11 \mathrm{SE}$ (general-purpose statistical software package by StataCorp) software were used to analyze data. The access to the final dataset was possible only for the principal investigator and the results were given only by the publication.

\section{Results}

\section{Characteristics of patients}

According to the flowchart in Fig. 1, a total of 787 people were screened (medical history). One hundred and fourteen patients met the eligibility criteria, of whom 15 declined and 7 couldn't participate. Ninety-two participants were randomized and 3 patients in GC group and 2 patients in the placebo group did not receive allocated intervention (refused to participate for personal reasons). Thus 87 participants completed the first visit (cardamom $n=43$; placebo $n=44$ ). Furthermore, 6 patients did not complete the study (for personal reasons and travelled; cardamom $n=3$; placebo $n=3$ ). In addition, the baseline values of blood biomarkers of one patient in the placebo group were not available. Finally, the data of 87 patients were analyzed according to the m-ITT.

The general characteristics, physical activity level, and the degree of fatty liver of 87 overweight or obese NAFLD patients are presented in Table 1. Patients had age and BMI of about $45 \mathrm{yrs}$. and $30 \mathrm{~kg} / \mathrm{m}^{2}$, respectively and there were 
more numbers of male than female, married, employee or free job/retired, had nearly similar educations, in moderate and high economic levels, and low physical activity. The mean of supplement compliance by using capsule counting was more than $95 \%$ for both GC and placebo groups.

Baseline characteristics were similar between patients, with the exception of the cardamom group that have higher dietary vitamin $\mathrm{E}$ intake (Tables 1,2,3).

\section{Changes in dietary intakes, degree of fatty liver, and} blood biomarkers

The dietary intakes during the study were almost similar between groups, except for significantly higher dietary intake of vitamins $\mathrm{E}$ and $\mathrm{B} 6$ in the cardamom group $(P<$ 0.05 , Table 3) which were considered as confounders in the final analysis. Within cardamom group, the mean difference of AST was not significant $(P>0.05)$, whereas the

Table 1 General characteristics and physical activity level of overweight/obese patients with non-alcoholic fatty liver disease (NAFLD)

\begin{tabular}{|c|c|c|c|c|c|}
\hline \multicolumn{3}{|l|}{ Variables } & Cardamom $(n=43) \mathrm{n}(\%)$ or Mean(SD) & Placebo $(n=44) \mathrm{n}(\%)$ or Mean(SD) & $P$-value \\
\hline \multicolumn{3}{|l|}{ Age (yrs) } & $45.5(8.9)$ & $45.0(7.7)$ & $0.7^{*}$ \\
\hline \multirow[t]{2}{*}{ Gender } & \multicolumn{2}{|l|}{ Male } & $27(62.8)$ & $27(61.4)$ & $0.8^{* *}$ \\
\hline & \multicolumn{2}{|c|}{ Female } & $16(37.2)$ & 17(38.6) & \\
\hline \multicolumn{3}{|l|}{ Height (cm) } & $166.9(10.3)$ & $169.5(9.5)$ & $0.3^{*}$ \\
\hline \multirow[t]{2}{*}{ Marriage status } & \multicolumn{2}{|l|}{ single } & $4(9.3)$ & $7(15.9)$ & $0.3^{* *}$ \\
\hline & \multicolumn{2}{|c|}{ married } & 39(90.7) & $37(84.1)$ & \\
\hline \multirow[t]{2}{*}{ Job status } & \multicolumn{2}{|c|}{$\begin{array}{l}\text { employee, free job/ } \\
\text { retired }\end{array}$} & $32(74.4)$ & $30(68.2)$ & $0.5^{* *}$ \\
\hline & \multicolumn{2}{|c|}{ housewife, unemployed } & $11(25.6)$ & 14(31.8) & \\
\hline \multirow[t]{2}{*}{ Education level } & \multicolumn{2}{|c|}{ up to associate degree } & 18(41.9) & $20(45.5)$ & $0.7^{* *}$ \\
\hline & \multicolumn{2}{|c|}{ Bachelor and higher } & $25(58.1)$ & $24(54.5)$ & \\
\hline \multirow[t]{3}{*}{ Economic level } & \multicolumn{2}{|c|}{ Low ( $\leq 3$ living items) } & $0(0)$ & $0(0)$ & $0.1^{* *}$ \\
\hline & \multicolumn{2}{|c|}{$\begin{array}{l}\text { moderate (4-6 living } \\
\text { items) }\end{array}$} & 12(27.9) & $6(13.6)$ & \\
\hline & \multicolumn{2}{|c|}{ High ( $\geq 7$ living items) } & $31(72.1)$ & 38(86.4) & \\
\hline \multirow[t]{3}{*}{ Physical activity level (Baseline) } & \multicolumn{2}{|c|}{$\begin{array}{l}\text { low (<600 MET- } \\
\text { minutes/week) }\end{array}$} & 38(88.4) & $34(77.3)$ & $0.1^{* *}$ \\
\hline & \multicolumn{2}{|c|}{$\begin{array}{l}\text { Moderate ( } 600 \text { to < } \\
1500 \text { MET-minutes/ } \\
\text { week) }\end{array}$} & $5(11.6)$ & $10(22.7)$ & \\
\hline & \multicolumn{2}{|c|}{$\begin{array}{l}\text { High ( } \geq 1500 \text { MET- } \\
\text { minutes/week) }\end{array}$} & $0(0)$ & $0(0)$ & \\
\hline \multirow[t]{3}{*}{ Physical activity level (After 3 months) } & \multicolumn{2}{|c|}{$\begin{array}{l}\text { low (<600 MET- } \\
\text { minutes/week) }\end{array}$} & 29(67.4) & $34(77.3)$ & $0.2^{\$}$ \\
\hline & \multicolumn{2}{|c|}{$\begin{array}{l}\text { Moderate (600 to < } \\
1500 \text { MET-minutes/ } \\
\text { week) }\end{array}$} & $12(27.9)$ & $6(13.6)$ & \\
\hline & \multicolumn{2}{|c|}{$\begin{array}{l}\text { High ( } \geq 1500 \text { MET- } \\
\text { minutes/week) }\end{array}$} & $2(4.7)$ & $4(9.1)$ & \\
\hline \multirow[t]{4}{*}{ Fatty liver (Baseline) } & & No & $0(0)$ & $0(0)$ & $0.1^{* *}$ \\
\hline & \multirow[t]{3}{*}{ Yes } & Mild & $27(62.8)$ & $34(77.3)$ & \\
\hline & & Moderate & $16(37.2)$ & $10(22.7)$ & \\
\hline & & Severe & $0(0)$ & $0(0)$ & \\
\hline \multirow[t]{4}{*}{ Fatty liver (After 3 months) } & & No & 18(41.8) & $2(4.5)$ & $<0.001^{* *}$ \\
\hline & \multirow[t]{3}{*}{ Yes } & Mild & $22(51.2)$ & $34(77.3)$ & \\
\hline & & Moderate & $3(7.0)$ & $8(18.2)$ & \\
\hline & & Severe & $0(0)$ & $0(0)$ & \\
\hline
\end{tabular}


Table 2 Comparison of baseline mean for weight, BMI, Sirt1, inflammatory factors, and liver enzymes in overweight/obese patients with non-alcoholic fatty liver disease (NAFLD)

\begin{tabular}{llll}
\hline Variables & Cardamom $(n=43)$ Mean(SD) & Placebo $(n=44)$ Mean(SD) & $P$-value \\
\hline Weight $(\mathrm{kg})$ & $85.2(11.3)$ & $88.6(13.2)$ & $0.2^{*}$ \\
BMI $(\mathrm{kg} / \mathrm{m} 2)$ & $30.5(2.4)$ & $30.7(3.2)$ & $0.6^{* *}$ \\
Sirt1 $(\mathrm{ng} / \mathrm{ml})$ & $1.3(0.5)$ & $1.2(0.5)$ & $0.6^{*}$ \\
TNF-a $(\mathrm{ng} / \mathrm{l})$ & $16.7(4.6)$ & $15.9(3.4)$ & $0.3^{*}$ \\
IL-6 $(\mathrm{ng} / \mathrm{l})$ & $9.7(3.0)$ & $9.3(2.6)$ & $0.5^{*}$ \\
hs-CRP $(\mathrm{mg} / \mathrm{l})$ & $5.5(3.0)$ & $5.4(3.2)$ & $0.8^{* *}$ \\
ALT (u/l) & $44.5(16.4)$ & $41.8(12.4)$ & $0.4^{* *}$ \\
AST (u/l) & $26.0(9.3)$ & $25.1(8.0)$ & $0.7^{* *}$ \\
\hline
\end{tabular}

*t-test; **Mann-Whitney; BMI body mass index, Sirt1 sirtuin-1, TNF- $a$ tumor necrosis factor-alpha, IL-6 interleukin-6, $h s$-CRP high sensitive c-reactive protein, ALT alanine transaminase, AST aspartate transaminase

weight, BMI, ALT, IL- 6 , TNF- $\alpha$, and hs-CRP decreased and Sirt1 increased significantly $(P<0.05)$. Within placebo group, the mean difference of weight, BMI, hs-CRP, ALT, and AST were not significant $(P>0.05)$, but the IL-6 and TNF- $\alpha$ decreased and Sirt1 increased significantly $(P<$ $0.05)$. At the end, compared to placebo, cardamom significantly improved fatty liver.

According to the time-by-treatment interaction effect in both unadjusted and adjusted analysis model, ALT, IL-6, TNF- $\alpha$, and hs-CRP decreased and Sirt1 increased significantly among cardamom group in comparison with the placebo group $(P<0.05)$. The time-by-treatment interaction effect had trend for weight $(P=0.051)$ and BMI $(P$ $=0.06)$ in the unadjusted model due to a small but non-significant decrease in the cardamom group more than the placebo group (Table 4).

\section{Safety}

The patients reported no side effects associated with the treatment. Only one patient in the placebo group reported nausea and constipation in one of his follow up.

\section{Discussion}

This trial for the first time assessed the effects of GC on blood inflammatory biomarkers, liver enzymes, and Sirt1 in overweight/obese NAFLD patients. According to time-by-treatment interaction effect in both unadjusted and adjusted analysis model, ALT, IL- 6 , TNF- $\alpha$, and hs-CRP decreased and Sirt1 increased significantly among cardamom group in comparison with the placebo group. Moreover, the improvements in the degree of fatty liver in cardamom group was significantly higher than the placebo group. The decrease of the weight and BMI in cardamom group had a trend in comparison with the placebo group in unadjusted analysis model.

The results of different studies on the effects of cardamom or polyphenol-rich foods showed some controversies and some of them are presented as follows.
The polyphenols, especially resveratrol, are activators of Sirt1 [53, 54] and they can improve obesity [55]. In our study, cardamom increased the serum Sirt1 significantly; however, the decrease of weight and BMI were not significant. The reasons are likely short duration and lower sample size of the study. Furthermore, in an experimental study on streptozotocin-induced diabetic rats, treatment with low-, intermediate-, or high-polyphenol cocoa for 16 weeks (i.e., $0.12,2.9$ or $22.9 \mathrm{mg} / \mathrm{kg} /$ day of polyphenols) improved Sirt1 activity [56]. Sirts, particularly Sirt1, deacylate histones/proteins and have a number of activities including anti-inflammatory activity that may prevent and reduce the complications, development, and progression of NAFLD [19].

Serum level of Sirt1 was measured in this study. Sirt1 was primarily represented as a nuclear protein [57] and leukocytes (peripheral blood mononuclear cell [PBMC]) have been used for determining Sirt1 expression [58]. However, it was demonstrated that Sirt1 moves between the nucleus and cytoplasm. Sirt1 has been recently determined in the serum, in spite of the fact that its exact origin is unclear [57]. Serum Sirt1 has been reported as a potential biomarker for some diseases such as aging-associated diseases [57].

In two separate animal studies, cardamom significantly decreased weight gain and serum AST and ALT levels $[59,60]$. In line with this study, the cardamom in diabetic patients for 8 weeks have no significant effects on measures of weight, BMI, waist, and hs-CRP [61]. This may be attributed to the type and form of the supplementation and the duration of the intervention.

Two cellular studies on cardamom demonstrated the suppression and inhibition of IL- 6 and TNF- $\alpha$ release $[62,63]$. The beneficial effects of cardamom on inflammatory factors including IL-6, TNF- $\alpha$, and NF- $\mathrm{kB}$ [64-66] and serum AST and ALT levels [66-71] had been observed in most of the animal models.

Cardamom supplementation in hyperlipidemic, overweight, and obese pre-diabetic women for 8 weeks 
Table 3 Dietary intakes of overweight/obese patients with non-alcoholic fatty liver disease (NAFLD)

\begin{tabular}{|c|c|c|c|c|c|}
\hline \multicolumn{2}{|l|}{ Dietary intakes } & \multirow{2}{*}{$\begin{array}{l}\text { Cardamom }(n=43) \text { Mean(SD) } \\
2309.3(763.3)\end{array}$} & \multirow{2}{*}{$\frac{\text { Placebo }(n=44) \text { Mean(SD) }}{2164.6(761.6)}$} & \multicolumn{2}{|c|}{$P$-value } \\
\hline Energy (kcal) & Baseline & & & $0.3^{*}$ & $0.4^{* *}$ \\
\hline & 1.5 Months & $1857.8(563.7)$ & 1871.1(641.1) & 0.9 & \\
\hline & 3 Months & 1947.5(656.7) & 1978.4(636.8) & 0.8 & \\
\hline \multirow[t]{3}{*}{ Protein (g) } & Baseline & $91.3(37.8)$ & 83.7(34.4) & 0.3 & 0.3 \\
\hline & 1.5 Months & $77.1(34.1)$ & 74.8(31.6) & 0.7 & \\
\hline & 3 Months & 79.6(31.7) & $83.1(30.4)$ & 0.7 & \\
\hline \multirow[t]{3}{*}{ Protein (\%) } & Baseline & $15.8(4.2)$ & $15.5(4.1)$ & 0.7 & 0.6 \\
\hline & 1.5 Months & $16.2(3.7)$ & $15.9(3.7)$ & 0.6 & \\
\hline & 3 Months & $16.4(4.4)$ & $16.9(3.5)$ & 0.5 & \\
\hline \multirow[t]{3}{*}{ Carbohydrate (g) } & Baseline & $275.3(110.7)$ & $261.1(94.0)$ & 0.5 & 0.3 \\
\hline & 1.5 Months & $221.6(76.4)$ & 234.6(80.6) & 0.6 & \\
\hline & 3 Months & 231.1(90.3) & 239.5(81.1) & 0.6 & \\
\hline \multirow[t]{3}{*}{ Carbohydrate (\%) } & Baseline & $47.5(10.3)$ & $48.7(9.8)$ & 0.5 & 0.7 \\
\hline & 1.5 Months & $47.8(8.1)$ & $50.5(6.6)$ & 0.08 & \\
\hline & 3 Months & $47.3(7.8)$ & 48.6(7.1) & 0.4 & \\
\hline \multirow[t]{3}{*}{ Fat (g) } & Baseline & $99.2(36.9)$ & 89.9(43.9) & 0.2 & 0.5 \\
\hline & 1.5 Months & $78.0(26.6)$ & $75.1(30.6)$ & 0.3 & \\
\hline & 3 Months & $82.3(29.6)$ & $81.4(34.2)$ & 0.5 & \\
\hline \multirow[t]{3}{*}{ Fat (\%) } & Baseline & $38.7(8.6)$ & $37.2(8.4)$ & 0.4 & 0.8 \\
\hline & 1.5 Months & $38.0(6.7)$ & $35.8(5.2)$ & 0.1 & \\
\hline & 3 Months & $38.2(6.3)$ & $36.8(6.8)$ & 0.3 & \\
\hline \multirow[t]{3}{*}{ Cholesterol (mg) } & Baseline & $234.4(143.5)$ & $221.9(174.5)$ & 0.3 & 0.8 \\
\hline & 1.5 Months & $208.0(134.4)$ & $186.1(141.6)$ & 0.3 & \\
\hline & 3 Months & $290.6(375.1)$ & $255.3(154.9)$ & 0.4 & \\
\hline \multirow[t]{3}{*}{ Saturated fat (g) } & Baseline & $26.0(11.2)$ & $24.0(13.7)$ & 0.4 & 0.7 \\
\hline & 1.5 Months & 21.2(9.6) & $21.2(11.7)$ & 0.7 & \\
\hline & 3 Months & 23.8(11.3) & $22.8(8.7)$ & 0.8 & \\
\hline \multirow[t]{3}{*}{ Monounsaturated fatty acid (g) } & Baseline & $36.2(14.3)$ & $32.9(16.9)$ & 0.1 & 0.6 \\
\hline & 1.5 Months & $28.3(10.0)$ & $27.5(11.4)$ & 0.5 & \\
\hline & 3 Months & $30.5(11.2)$ & 29.1(11.0) & 0.3 & \\
\hline \multirow[t]{3}{*}{ Polyunsaturated fatty acid (g) } & Baseline & $26.3(13.1)$ & $22.4(12.2)$ & 0.08 & 0.1 \\
\hline & 1.5 Months & $20.2(9.2)$ & 19.5(8.8) & 0.5 & \\
\hline & 3 Months & 19.2(8.6) & $20.1(12.1)$ & 0.7 & \\
\hline \multirow[t]{3}{*}{ Vitamin A (RAE) $(\mu \mathrm{g})$} & Baseline & $465.7(449.5)$ & $419.1(434.7)$ & 0.4 & 0.3 \\
\hline & 1.5 Months & $285.1(222.8)$ & $375.5(326.9)$ & 0.2 & \\
\hline & 3 Months & $365.5(349.3)$ & $397.2(246.2)$ & 0.1 & \\
\hline \multirow[t]{3}{*}{ Carotenoids (mg) } & Baseline & 10.3(9.3) & $8.7(8.2)$ & 0.3 & 0.2 \\
\hline & 1.5 Months & $6.9(6.7)$ & $6.9(7.3)$ & 0.8 & \\
\hline & 3 Months & $7.2(7.5)$ & $8.9(6.3)$ & 0.08 & \\
\hline \multirow[t]{3}{*}{ Vitamin C (mg) } & Baseline & $88.7(92.1)$ & $93.2(84.0)$ & 0.7 & 0.7 \\
\hline & 1.5 Months & $84.6(83.4)$ & $79.1(60.2)$ & 0.8 & \\
\hline & 3 Months & $76.0(52.0)$ & $87.1(61.9)$ & 0.4 & \\
\hline \multirow[t]{2}{*}{ Calcium (mg) } & Baseline & $968.3(589.4)$ & $872.0(530.4)$ & 0.3 & 0.05 \\
\hline & 1.5 Months & $925.4(390.3)$ & $951.3(490.1)$ & 0.7 & \\
\hline
\end{tabular}


Table 3 Dietary intakes of overweight/obese patients with non-alcoholic fatty liver disease (NAFLD) (Continued)

\begin{tabular}{|c|c|c|c|c|c|}
\hline Dietary intakes & & Cardamom $(n=43)$ Mean(SD) & Placebo $(n=44)$ Mean(SD) & $P$-value & \\
\hline & 3 Months & $930.5(485.1)$ & $1145.1(533.4)$ & 0.03 & \\
\hline \multirow[t]{3}{*}{ Iron (mg) } & Baseline & $15.1(6.6)$ & $14.0(4.7)$ & 0.4 & 0.7 \\
\hline & 1.5 Months & $11.6(4.0)$ & $11.5(3.8)$ & 0.8 & \\
\hline & 3 Months & $12.3(5.0)$ & $11.7(4.4)$ & 0.5 & \\
\hline \multirow[t]{3}{*}{ Vitamin D $(\mu \mathrm{g})$} & Baseline & $0.9(1.4)$ & $1.5(3.0)$ & 0.7 & 0.7 \\
\hline & 1.5 Months & $0.9(1.5)$ & $1.6(2.4)$ & 0.1 & \\
\hline & 3 Months & $1.2(1.2)$ & $2.1(2.1)$ & 0.03 & \\
\hline \multirow[t]{3}{*}{ Vitamin E (mg) } & Baseline & $31.7(16.2)$ & $24.3(12.7)$ & 0.01 & 0.01 \\
\hline & 1.5 Months & 23.8(11.2) & $22.3(9.7)$ & 0.4 & \\
\hline & 3 Months & $22.6(10.3)$ & $23.8(11.3)$ & 0.8 & \\
\hline \multirow[t]{3}{*}{ Vitamin B1 (mg) } & Baseline & $1.6(0.7)$ & 1.6(0.6) & 0.6 & 0.7 \\
\hline & 1.5 Months & $1.4(0.5)$ & $1.4(0.5)$ & 0.9 & \\
\hline & 3 Months & $1.5(0.5)$ & $1.5(0.5)$ & 0.6 & \\
\hline \multirow[t]{3}{*}{ Vitamin B2 (mg) } & Baseline & $1.9(1.0)$ & $1.7(0.8)$ & 0.6 & 0.06 \\
\hline & 1.5 Months & $1.6(0.6)$ & $1.6(0.7)$ & 0.9 & \\
\hline & 3 Months & $1.6(0.7)$ & $2.0(0.8)$ & 0.07 & \\
\hline \multirow[t]{3}{*}{ Vitamin B3 (mg) } & Baseline & $27.0(13.5)$ & 23.9(12.7) & 0.2 & 0.4 \\
\hline & 1.5 Months & $21.8(12.9)$ & $19.9(11.5)$ & 0.4 & \\
\hline & 3 Months & $21.1(8.2)$ & $21.9(10.3)$ & 0.8 & \\
\hline \multirow[t]{3}{*}{ Vitamin B6 (mg) } & Baseline & $1.9(0.9)$ & $1.7(0.7)$ & 0.2 & 0.02 \\
\hline & 1.5 Months & $1.6(0.7)$ & $1.5(0.7)$ & 0.4 & \\
\hline & 3 Months & $1.5(0.5)$ & $1.7(0.6)$ & 0.1 & \\
\hline \multirow[t]{3}{*}{ Folate (DFE) $(\mu \mathrm{g})$} & Baseline & 405.7(192.2) & $457.2(182.8)$ & 0.8 & 0.5 \\
\hline & 1.5 Months & $370.8(176.5)$ & $363.7(157.1)$ & 0.6 & \\
\hline & 3 Months & $388.0(183.1)$ & $348.8(130.9)$ & 0.2 & \\
\hline \multirow[t]{3}{*}{ Vitamin B12 $(\mu \mathrm{g})$} & Baseline & $4.1(2.5)$ & $4.1(2.8)$ & 0.8 & 0.9 \\
\hline & 1.5 Months & $3.5(2.1)$ & $3.6(2.5)$ & 0.9 & \\
\hline & 3 Months & 4.6(3.8) & $4.4(2.0)$ & 0.5 & \\
\hline \multirow[t]{3}{*}{ Vitamin K $(\mu \mathrm{g})$} & Baseline & 257.3(489.8) & 198.3(371.0) & 0.5 & 0.4 \\
\hline & 1.5 Months & 118.9(225.8) & 147.9(233.4) & 0.2 & \\
\hline & 3 Months & 195.0(373.0) & 113.2(193.2) & 0.8 & \\
\hline \multirow[t]{3}{*}{ Zinc (mg) } & Baseline & $11.8(5.2)$ & $11.5(4.8)$ & 0.9 & 0.7 \\
\hline & 1.5 Months & $9.7(3.6)$ & $10.4(4.1)$ & 0.5 & \\
\hline & 3 Months & $11.5(6.2)$ & 11.4(3.8) & 0.6 & \\
\hline \multirow[t]{3}{*}{ Selenium $(\mu \mathrm{g})$} & Baseline & $98.9(48.1)$ & $106.9(52.4)$ & 0.4 & 0.7 \\
\hline & 1.5 Months & $85.6(42.3)$ & $94.1(38.7)$ & 0.3 & \\
\hline & 3 Months & $101.4(50.7)$ & $103.3(43.5)$ & 0.7 & \\
\hline \multirow[t]{3}{*}{ Total fiber (g) } & Baseline & $30.3(16.5)$ & $26.6(15.3)$ & 0.2 & 0.3 \\
\hline & 1.5 Months & 26.1(13.1) & $22.4(10.2)$ & 0.1 & \\
\hline & 3 Months & $24.7(12.7)$ & $25.2(12.2)$ & 0.6 & \\
\hline
\end{tabular}

*Total of the column: t-test or Mann-Whitney; **Total of the column: Two way repeated measures-ANOVA (TWRM-ANOVA) 
Table 4 The changes of weight, BMI, Sirt1, inflammatory factors, and liver enzymes in overweight/obese NAFLD patients

\begin{tabular}{|c|c|c|c|c|c|c|c|c|}
\hline \multirow[t]{2}{*}{ Variables } & \multirow[t]{2}{*}{ Intervention } & \multirow{2}{*}{$\begin{array}{l}\text { Baseline } \\
\text { Mean(SD) }\end{array}$} & \multirow{2}{*}{$\begin{array}{l}3 \text { Months } \\
\text { Mean(SD) }\end{array}$} & \multirow{2}{*}{$\begin{array}{l}P- \\
\text { value }\end{array}$} & \multirow{2}{*}{$\begin{array}{l}\text { Mean Difference } \\
(95 \% \mathrm{Cl})\end{array}$} & \multicolumn{3}{|l|}{$P$-value ${ }^{\#}$} \\
\hline & & & & & & Time & Treatment & Interaction \\
\hline \multirow[t]{2}{*}{ Weight (kg) } & Cardamom $(n=43)$ & $85.2(11.3)$ & $84.2(11.3)$ & $<0.001$ & $-1.0(-1.7,-0.2)$ & $<0.001$ & 0.1 & 0.051 \\
\hline & Placebo $(n=44)$ & $88.6(13.2)$ & $88.2(13.9)$ & 0.2 & $-0.4(-1.27,0.47)$ & 0.001 & 0.1 & 0.2 \\
\hline \multirow[t]{2}{*}{$\mathrm{BMI}\left(\mathrm{kg} / \mathrm{m}^{2}\right)^{*}$} & Cardamom $(n=43)$ & $30.5(2.4)$ & $30.1(2.4)$ & $<0.001$ & $-0.4(-0.55,-0.24)$ & $<0.001$ & 0.8 & 0.06 \\
\hline & Placebo $(n=44)$ & $30.7(3.2)$ & $30.6(3.4)$ & 0.1 & $-0.1(-0.31,0.11)$ & $<0.001$ & 0.8 & 0.2 \\
\hline \multirow[t]{2}{*}{ Sirt1 $(\mathrm{ng} / \mathrm{ml})^{* *}$} & Cardamom $(n=43)$ & $1.3(0.5)$ & $1.7(0.5)$ & $<0.001$ & $0.4(0.36,0.43)$ & $<0.001$ & 0.054 & $<0.001$ \\
\hline & Placebo $(n=44)$ & $1.2(0.5)$ & $1.3(0.5)$ & 0.003 & $0.1(0.06,0.13)$ & $<0.001$ & 0.04 & $<0.001$ \\
\hline \multirow[t]{2}{*}{ TNF-a (ng/l) } & Cardamom $(n=43)$ & 16.7(4.6) & $8.7(4.3)$ & $<0.001$ & $-8.0(-8.2,-7.7)$ & $<0.001$ & 0.001 & $<0.001$ \\
\hline & Placebo $(n=44)$ & $15.9(3.4)$ & $15.2(3.7)$ & 0.03 & $-0.7(-0.9,-0.4)$ & $<0.001$ & $<0.001$ & $<0.001$ \\
\hline \multirow[t]{2}{*}{ IL-6 (ng/l) } & Cardamom $(n=43)$ & $9.7(3.0)$ & $5.0(2.6)$ & $<0.001$ & $-4.7(-4.8,-4.5)$ & $<0.001$ & 0.008 & $<0.001$ \\
\hline & Placebo $(n=44)$ & $9.3(2.6)$ & $8.4(2.5)$ & 0.001 & $-0.9(-1.0,-0.7)$ & $<0.001$ & 0.009 & $<0.001$ \\
\hline \multirow[t]{2}{*}{$\mathrm{hs}-\mathrm{CRP}(\mathrm{mg} / \mathrm{l}) \wedge$} & Cardamom $(n=43)$ & $5.5(3.0)$ & $3.7(2.0)$ & $<0.001$ & $-1.8(-1.9,-1.6)$ & $<0.001$ & 0.3 & $<0.001$ \\
\hline & Placebo $(n=44)$ & $5.4(3.2)$ & $5.3(3.0)$ & 0.08 & $-0.1(-0.3,0.1)$ & 0.01 & 0.4 & $<0.001$ \\
\hline \multirow[t]{2}{*}{$\operatorname{ALT}(\mathrm{u} / \mathrm{l})^{* *}$} & Cardamom $(n=43)$ & $44.5(16.4)$ & $31.8(12.0)$ & $<0.001$ & $-12.7(-13.6,-11.7)$ & $<0.001$ & 0.1 & $<0.001$ \\
\hline & Placebo $(n=44)$ & $41.8(12.4)$ & $41.3(12.9)$ & 0.5 & $-0.5(-1.3,0.3)$ & 0.006 & 0.1 & $<0.001$ \\
\hline \multirow[t]{2}{*}{$\operatorname{AST}(u / I) \wedge$} & Cardamom $(n=43)$ & $26.0(9.3)$ & $25.0(8.8)$ & 0.08 & $-1.0(-1.6,-0.4)$ & 0.2 & 0.9 & 0.1 \\
\hline & Placebo $(n=44)$ & $25.1(8.0)$ & $25.2(7.6)$ & 0.8 & $0.1(-0.4,0.6)$ & 0.01 & 0.7 & 0.3 \\
\hline
\end{tabular}

*Inversely transformed; **Transformed by square root; $\wedge$ Logarithmically transformed; $\$$ Paired t-test; \#Two way repeated measures-ANOVA (TWRM-ANOVA), top row: unadjusted; bottom row: adjusted for vitamins E and B6 intake; BMI body mass index, Sirt1 sirtuin-1, TNF- $a$ tumor necrosis factor-alpha, IL-6 interleukin-6, $h s-$ $C R P$ high sensitive c-reactive protein, ALT alanine transaminase, AST aspartate transaminase

decreased serum hs-CRP level after adjustment of some covariates [72]. Another human study on the effects of daily consumption of Arabic coffee with two different doses of cardamom did not show significant alteration in the concentration of ALT, AST, and C-reactive protein (CRP). This could be attributed to the fact that participants were healthy subjects who had normal levels of CRP, and no indications of inflammation [73].

Cardamom's bioactive principles (i.e. 1,8-cineol [eucalyptol], beta-pinene, geraniol) had been revealed to have anti-inflammatory activity by binding to TNF- $\alpha$, IL- 1 beta, IL-4, and IL-5 [74]. In addition, clinical trial reviews of natural products including ginger, turmeric, and other polyphenol-rich compounds $[75,76]$ and most studies on polyphenolic compounds have showed decreased levels of inflammatory factors including IL- 6 , TNF- $\alpha$, and hs-CRP in healthy or non-healthy subjects [77-84].

The reasons why our results were in accordance or contrary to other studies can be attributed to the difference in the type and design of the study, the sample size, the type of disease, the type and form of supplementation, the intervention duration, and the higher or lower values of the serum profiles at the beginning of the study.

The reported mechanisms for beneficial effects of GC on inflammation include decreased infiltration of inflammatory cells, lipid peroxidation, and levels of advanced oxidation protein products (AOPP), increase of antioxidant enzymes activity [60, 67, 85], inhibition of inflammatory mediators including COX-2, iNOS, and NF-kB $[40,62,63,70,86,87,88]$, decrease of hemolysis by the vitamin E deficiency [89], and increase of PPARy activity and cytotoxicity of natural killer cells [74].

The explained mechanisms in the improvement of the liver enzymes and the degree of fatty liver by cardamom include decrease of lipid peroxidation, increase of antioxidant capacity, cardamom active contents including phenols, polyphenols, minerals $(\mathrm{Cu}, \mathrm{Mn})[59,60,67,68,89-91]$, 1,8-cineol [92], and flavonoids [70].

The observed effects of GC in NAFLD patients would make this study relevant. Although GC had been hypothetically used in the treatment of some disorders, it can be used in humans for further study in different diseases, particularly NAFLD. Also, the emerging rates of obesity and, consequently, NAFLD should be given more attention.

This study has several strengths. First, the double-blinded stratified blocked randomization design; Second, the inclusion of patients with newly diagnosed NAFLD who had not yet received treatment; Third, considering multiple eligibility criteria; Fourth, protocol publication, Fifth, the determining of dietary intakes and physical activity status and adjusting the statistical analysis for them and other potential confounders; Sixth, considering control group. These strengths are likely preferable in comparison with few other clinical trials that have evaluated the effects of any spices on NAFLD patients. 
However, our study had some limitations. First, the sample size was small; Second, the intervention duration was short to understand the real effects of cardamom supplementation; Third, disregarding non-obese NAFLD patients. Fourth, self-reporting of diet and physical activity; Fifth, failure to perform liver biopsy and measure gamma-glutamyl transferase (GGT); Sixth, failure to check the bioavailability of GC and measure serum levels of its components; Seventh, 24-h food recall is not a good index for assessing the usual food intake; and Eighth, failure to measure body composition. Even so, this study is the first trial to evaluate the effects of GC on overweight/obese NAFLD patients.

\section{Conclusion}

GC supplementation in obese NAFLD patients reduced inflammatory biomarkers (IL-6, TNF- $\alpha$, and hs-CRP), ALT, and the degree of fatty liver and increased Sirt1 compared with placebo. Accordingly, GC may be useful in other metabolic diseases associated with inflammation. Further trials and considering the mentioned limitations are needed to confirm these results.

\section{Abbreviations}

AOPP: Advanced oxidation protein products; BMI: Body mass index; CEO: Cardamomum essential oil; COX-2: Cyclooxygenase-2; ELISA: Enzymelinked immunosorbent assay; GC: Green cardamom; GC-MS: Gas chromatography mass spectrometry; HPLC: High-performance liquid chromatography; hs-CRP: High-sensitivity C-reactive protein; IL-

1ß: Interleukin-1 beta; IL-6: Interleukin-6; iNOS: Inducible-nitric oxide synthase; IPAQ: International physical activity questionnaire; ITT: Intention to treat; NAFLD: Non-alcoholic fatty liver disease; NASH: Non-alcoholic steatohepatitis; NF-KB: Nuclear factor kappa-light-chain-enhancer of activated B cells; NIOC: National Iranian Oil Company; PGC-1a: PPAR- $\gamma$ co-activator-1 alpha; PPAR: Peroxisome proliferation activated receptor; ROS: Reactive oxygen species; Sirt-1: Sirtuin-1: SOD: Superoxide dismutase; TG: Triglyceride: TMRC: Traditional Medicine Research Center; TNF-a: Tumor necrosis factoralpha; TPN: Total parenteral nutrition; TWRM-ANOVA: Two way repeated measures-analysis of covariance

\section{Acknowledgments}

This research has been supported by Tehran University of Medical Sciences grant no. 94-03-161-30123. The cooperation of the NIOC central hospital of Tehran is acknowledged.

\section{Availability of data and supporting materials}

Not applicable.

\section{Funding}

Funding was supported by the Tehran University of Medical Sciences (Code: 30123-161-03-94)

\section{Authors' contributions}

MDM, GS, and SAK conceived and developed the idea for the paper and revised the manuscript. SM, SMA, MBF, and SAJT contributed to data collection. MBF wrote numerous drafts. MQ contributed to statistical interpretations. All authors read and approved the final manuscript.

\section{Ethics approval and consent to participate}

This trial was approved by the ethics committee of the Tehran University of Medical Sciences (Ethical Code: IR.TUMS.REC.1394.791). An informed consent form (in Persian) obtained from all the patients. Participation was free, and a patient could withdraw at whatever point the person feels he/she was unable to continue. The lifestyle advice was presented free to the patients and there was no bar to receiving the other health care services of the center. Side-effects of the supplements (up to $3 \mathrm{~g} /$ day) had not been reported previously. The personal information of patients was kept secret before, during, and after the study.

\section{Consent for publication}

Not applicable.

\section{Competing interests}

The authors declare that they have no competing interests.

\section{Publisher's Note}

Springer Nature remains neutral with regard to jurisdictional claims in published maps and institutional affiliations.

\section{Author details}

${ }^{1}$ Department of Community Nutrition, School of Nutritional Sciences and Dietetics, Tehran University of Medical Sciences, No.44, Hojjatdoust Alley, Naderi Ave, Keshavarz Blvd, Tehran 1416643931, Iran. ${ }^{2}$ Department of Clinical Nutrition, School of Nutritional Sciences and Dietetics, Tehran University of Medical Sciences, Tehran, Iran. ${ }^{3}$ Non-Communicable Diseases Research Center, Alborz University of Medical Sciences, Karaj, Iran.

${ }^{4}$ Gastroenterohepatology Department, National Iranian Oil Company (NIOC) Central Hospital, Tehran, Iran. ${ }^{5}$ Baqiyatallah Research Center for

Gastroenterology and Liver Diseases (BRCGL), Baqiyatallah University of Medical Sciences, Tehran, Iran.

Received: 24 April 2018 Accepted: 1 August 2018

Published online: 25 September 2018

\section{References}

1. Sherlock S, Dooley J. Diseases of the Liver and Biliary System. 11th ed. Oxford: Blackwell Science; 2002. p. 423.

2. Adibi A, Jaberzadeh-Ansari M, Dalili AR, Omidifar N, Sadeghi M. Association between Nonalcoholic Fatty Liver Disease (NAFLD) and Coronary Artery Disease (CAD) in Patients with Angina Pectoris. Open J Med Imag. 2013;3: 97-101. https://doi.org/10.4236/ojmi.2013.33015.

3. Younossi ZM, Koenig AB, Abdelatif D, Fazel Y, Henry L, Wymer M. Global epidemiology of nonalcoholic fatty liver disease-Meta-analytic assessment of prevalence, incidence, and outcomes. Hepatology. 2016;64(1):73-84.

4. Fabbrini E, Sh S, Klein S. Obesity and Nonalcoholic Fatty Liver Disease: Biochemical, Metabolic and Clinical Implications. Hepatology. 2010;51(2): 679-89. https://doi.org/10.1002/hep.23280.

5. Nishioji K, Sumida Y, Kamaguchi M, Mochizuki N, Kobayashi M, Nishimura T, Yamaguchi K, Itoh Y. Prevalence of and risk factors for non-alcoholic fatty liver disease in a non-obese Japanese population, 2011-2012. J Gastroenterol. 2015;50(1):95-108. https://doi.org/10.1007/s00535-014-0948-9.

6. Amirkalali B, Poustchi H, Keyvani H, Khansari MR, Ajdarkosh H, Maadi M, Sohrabi MR, Zamani F. Prevalence of Non-Alcoholic Fatty Liver Disease and Its Predictors in North of Iran. Iranian J Public Health. 2014;43(9):1275-83.

7. Bagheri Lankarani K, Ghaffarpasand F, Mahmoodi M, Lotfi M, Zamiri N, Heydari ST, Fallahzadeh MK, Maharlouei N, Babaeinejad M, Mehravar S, Geramizadeh B. Non Alcoholic Fatty Liver Disease in Southern Iran: A Population Based Study. Hepat Mon. 2013;13(5):e9248.

8. Musso G, Molinaro F, Paschetta E, Gambino R, Cassader M. Lipid modifiers and NASH: statins, ezetimibe, fibrates, and other agents. In: McCullough AJ, Day CP, editors. Non-Alcoholic Fatty Liver Disease. Hoboken: Wiley Blackwell; 2013. p. 293-307.

9. Gaharwar R, Trikha S, Margekar SL, Jatav OP, Ganga PD. Study of Clinical Profile of Patients of Non Alcoholic Fatty Liver Disease and its Association with Metabolic Syndrome. J Assoc Physicians India. 2015; 63(1):12-6. PMID:26591121

10. National Guideline Centre (UK). Non-Alcoholic Fatty Liver Disease: Assessment and Management. London: National Institute for Health and Care Excellence (UK); 2016. (NICE Guideline, No. 49.) 5, Risk factors for NAFLD. Available from: https://www.ncbi.nlm.nih.gov/books/NBK384735/

11. Lau E, Carvalho D, Freitas P. Gut Microbiota: Association with NAFLD and Metabolic Disturbances. Biomed Res Int. 2015:979515, 9. https://doi.org/10. 1155/2015/979515. 
12. Colak Y, Ozturk O, Senates E, Tuncer I, Yorulmaz E, Adali G, Doganay L, Enc FY. SIRT1 as a potential therapeutic target for treatment of nonalcoholic fatty liver disease. Medical Sci Monit. 2011;17(5):HY5-9.

13. Sahebkar A. Potential efficacy of ginger as a natural supplement for nonalcoholic fatty liver disease. World J Gastroenterol. 2011;17(2):271-2. https://doi.org/10.3748/wjg.v17.i2.271.

14. McCullough A. The clinical features, diagnosis and natural history of nonalcoholic fatty liver disease. Clin Liver Dis. 2004;8(3):521-33. https://doi. org/10.1016/j.cld.2004.04.004.

15. Chung S, Yao H, Caito S, Hwang J, Arunachalam G, Rahman I. Regulation of SIRT1 in cellular functions: Role of polyphenols. Arch Biochem Biophys. 2010;501:79-90. https://doi.org/10.1016/j.abb.2010.05.003.

16. Farris PK. Innovative Cosmeceuticals: Sirtuin Activators and Anti-Glycation Compounds. Semin Cutan Med Surg. 2011;30:163-6. https://doi.org/10. 1016/j.sder.2011.05.004

17. Salminena A, Kaarniranta K, Kauppinenc A. Crosstalk between Oxidative Stress and SIRT1: Impact on the Aging Process. Int J Mol Sci. 2013;14:383459. https://doi.org/10.3390/ijms14023834.

18. Elliott PJ, Jirousek M. Sirtuins: Novel targets for metabolic disease. Curr Opin Investig Drugs. 2008;9(4):371-8.

19. Colak Y, Yesil A, Mutlu HH, Caklili OT, Ulasoglu C, Senates E, Takir M, Kostek O, Yilmaz Y, Yilmaz Enc F, Tasan G. A potential treatment of non-alcoholic fatty liver disease with SIRT1 activators. J Gastrointestin Liver Dis. 2014;23(3):311-9.

20. Salminena A, Kauppinenc A, Kaarniranta K. Phytochemicals suppress nuclear factor-kB signaling: impact on health span and the aging process. Curr Opin Clin Nutr Metab Care. 2012;15(1):23-8. https://doi.org/10.1097/MCO. Ob013e32834d3ae7.

21. Wu T, Liu YH, Fu YC, Liu XM, Zhou XH. Direct evidence of sirtuin downregulation in the liver of non-alcoholic fatty liver disease patients. Ann Clin Lab Sci. 2014 Sep 21:44(4):410-8.

22. Han X, Shen T, Lou H. Dietary Polyphenols and Their Biological Significance. Int J Mol Sci. 2007:8:950-88. PMCID: PMC3871896

23. Brglez Mojzer E, Knez Hrnčič M, Škerget M, Knez Ž, Bren U. Polyphenols: Extraction methods, antioxidative action, bioavailability and anticarcinogenic effects. Molecules. 2016;21(7):901

24. Kim JA, Kim DK, Kang OH, Choi YA, Park HJ, Choi SC, Kim TH, Yun KJ, Nah YH, Lee YM. Inhibitory effect of luteolin on TNF-a-induced IL-8 production in human colon epithelial cells. International immunopharmacology. 2005; 5(1):209-17. https://doi.org/10.1016/j.intimp.2004.09.027.

25. Hämäläinen M, Nieminen R, Vuorela P, Heinonen M, Moilanen E. Antiinflammatory effects of flavonoids: genistein, kaempferol, quercetin, and daidzein inhibit STAT-1 and NF-kappaB activations, whereas flavone, isorhamnetin, naringeninand pelargonidin inhibit only NF-kappaBactivation along with their inhibitory effect on iNOS expression and NO production in activated macrophages. Mediators of Inflamm. 2007; 2007: Article ID 45673. 10 pages. doi: https://doi.org/10.1155/2007/45673.

26. Kim HK, Park HR, Lee JS, Chung TS, Chung HY, Chung J. Down-regulation of iNOS and TNF-alpha expression by kaempferol via NF-kappaB inactivation in aged rats gingival tissues. Biogerontology. 2007;8(4):399-408.

27. Davis JM, Murphy EA, Martin DC. Effects of the dietary flavonoid quercetin upon performance and health. Curr Sports Med Rep. 2009;8(4):206-13. https://doi.org/10.1249/JSR.0b013e3181ae8959.

28. Da-Silva WS, Harney JW, Kim BW, Li J, Bianco SD, Crescenzi A, Christoffolete MA, Huang SA, Bianco AC. The small polyphenolic molecule kaempferol increases cellular energy expenditure and thyroid hormone activation. Diabetes. 2007;56(3):767-76.

29. Park MJ, Kim DI, Choi JH, Heo YR, Park SH. New role of irisin in hepatocytes: The protective effect of hepatic steatosis in vitro. Cell Signal. 2015; https:// doi.org/10.1016/j.cellsig.2015.04.010.

30. Dixon JB, Bhathal PS, Hughes NR, O'Brien PE. Nonalcoholic fatty liver disease: Improvement in liver histological analysis with weight loss. Hepatology. 2004;39:1647-54

31. Shah K, Stufflebam A, Hilton TN, Sinacore DR, Klein S, Villareal DT. Diet and exercise interventions reduce intrahepatic fat content and improve insulin sensitivity in obese older adults. Obesity. 2009;17:2162-8.

32. Deng YJ, Zhang YP, Yang QH, Han L, Liang YJ, He YF, Li YY, Wang GL, Lin CM, Zhang JW. Effects of Berberine on Hepatic Sirtuin 1-uncoupling Protein 2 Pathway in Non-alcoholic Fatty Liver Disease Rats Induced by High-fat Diet. Chinese Herbal Med. 2016;8(4):359-65.

33. Katan MB. Weight-loss diets for the prevention and treatment of obesity. $\mathrm{N}$ Engl J Med. 2009;360:923-5.
34. Zelber-Sagi S, Ratziu V, Oren R. Nutrition and physical activity in NAFLD: An overview of the epidemiological evidence. World J Gastroenterol. 2011; 17(29):3377-89. https://doi.org/10.3748/wjg.v17.i29.3377.

35. Daneshi-Maskooni M, Keshavarz SA, Mansouri S, Qorbani M, Alavian SM, Badri-Fariman M, Jazayeri-Tehrani SA, Sotoudeh G. The effects of green cardamom on blood glucose indices, lipids, inflammatory factors, paraxonase-1, sirtuin-1, and irisin in patients with nonalcoholic fatty liver disease and obesity: study protocol for a randomized controlled trial. Trials. 2017;18(1):260. https://doi.org/10.1186/s13063-017-1979-3

36. Jazayeri-Tehrani SA, Rezayat SM, Mansouri S, Qorbani M, Alavian SM, Daneshi-Maskooni M, Hosseinzadeh-Attar MJ. Efficacy of nanocurcumin supplementation on insulin resistance, lipids, inflammatory factors and nesfatin among obese patients with non-alcoholic fatty liver disease (NAFLD): a trial protocol. BMJ open. 2017;7(7):e016914.

37. Jazayeri-Tehrani SA, Rezayat SM, Mansouri S, Qorbani M, Alavian SM Daneshi-Maskooni M, Hosseinzadeh-Attar MJ. The nanocurcumin reduces appetite in obese patients with non-alcoholic fatty liver disease (nafld): a double-blind randomized placebo-controlled clinical trial. Nanomed J. 2018;5(2):67-76. https://doi.org/10.22038/nmj.10.22038/nmj. 2018.005.002.

38. Verma SK, Jain V, Katewa SS. Blood pressure lowering, fibrinolysis enhancing and antioxidant activities of Cardamom (Elettaria cardamomum). Indian J Biochem Biophys. 2009:46:503-6.

39. Vijayan KK, Madhusoodanan KJ, Radhakrishnan W, Ravindran PN. Chapter 12: Properties and end-uses of cardamom, Cardamom The genus Elettaria. Book. Abingdon-on-Thames: Taylor \& Francis; 2002.

40. Suneetha WJ, Krishnakantha TP. Cardamom Extract as Inhibitor of Human Platelet Aggregation. Phytother Res. 2005;19:437-40. https://doi. org/10.1002/ptr.1681.

41. Sengupta A, Bhattacharjee S. Cardamom (Elettaria cardamomum) and Its Active Constituent, 1,8-cineole. In: Aggarwal BB, Kunnumakkara AB, editors. Molecular Targets and Therapeutic Uses of Spices. Singapore: World Scientific Publishing Co. Pte. Ltd; 2009. p. 65-85.

42. Del Campo JA, Gallego-Durán R, Gallego P, Grande L. Genetic and Epigenetic Regulation in Nonalcoholic Fatty Liver Disease (NAFLD). Int J Mol Sci. 2018;19(3):911.

43. Ding RB, Bao J, Deng CX. Emerging roles of SIRT1 in fatty liver diseases. Int J Biol Sci. 2017;13(7):852-67.

44. Verma SK, Jain V, Singh DP. Effect of Greater cardamom (Amomum subulatum Roxb.) on blood lipids, fibrinolysis and total antioxidant status in patients with ischemic heart disease. Asian Pac J Trop Dis. 2012;2:S739-43.

45. Ekhlasi G, Shidfar F, Agah S, Merat S, Hosseini KAF. Effect of pomegranate juice intake on lipid profile in patients with nonalcoholic fatty liver disease. Razi J Med Sci. 2013;20(111):30-9. [in Farsi]

46. Musso G, Gambino R, Cassader M, Pagano G. A Meta-Analysis of Randomized Trials for the Treatment of Nonalcoholic Fatty Liver Disease. Hepatology. 2010:52:79-104.

47. Jazayeri S, Nouri M, Pour-Ebrahim R, Fakhrzadeh H, Larijani B. Food and nutrient intake status in urban population (20-60 years) of population research center of Tehran University of Medical Sciences. Iran J Diab Lipid. 2005:1(3):81-9. [in Farsi]

48. Qaffarpour M, Houshyar-Rad A, Kianfar H. Guides of home scales, conversion coefficients and percentage of Iranian foods. Tehran: Agricultural Sciences Publication; 2000. [in Farsi]

49. The IPAQ group. International physical activity questionnaire [Internet]. 2017 [cited 26 Feb 2017]. Available from: https://sites.google.com/site/theipaq/

50. Vafai-Najar A, Vahedian-Shahroodi M, Tehrani H, Dogonchi M, Lael-Monfared E. The effectiveness of physical activity training on depersonalization of employees. Iran J Health Educ Health Promot. Summer. 2015;3(2):116-24.

51. Baghiani-Moghaddam MH, Bakhtiari-Aghdam F, Asghari-Jafarabadi M, Allahverdipour H, Saeed Dabagh-Nikookheslat S, Nourizadeh R. Comparing the Results of Pedometer-Based Data and International Physical Activity Questionnaire (IPAQ). J Health Syst Res. 2013;9(6):605-12.

52. The lab tests online. Laboratory Methods Used For Medical Lab Testing (Enzyme-linked immunosorbent assay (ELISA)) [Internet]. 2012 [cited 26 Feb 2017]. Available from: https://labtestsonline.org/understanding/features/ methods/start/2/.

53. Ajami M, Pazoki-Toroudi $H$, Amani $H$, Nabavi SF, Braidy N, Vacca RA, Atanasov AG, Mocan A, Nabavi SM. Therapeutic role of sirtuins in neurodegenerative disease and their modulation by polyphenols. Neurosc Biobehav Rev. 2017;73:39-47. 
54. Berman AY, Motechin RA, Wiesenfeld MY, Holz MK. The therapeutic potential of resveratrol: a review of clinical trials. NPJ Precision Oncol. 2017; 1(1):35. https://doi.org/10.1038/s41698-017-0038-6.

55. Kelly GS. A review of the sirtuin system, its clinical implications, and the potential role of dietary activators like resveratrol: part 2. Altern Med Rev. 2010;15(4):313-29.

56. Duarte DA, Mariana Ap BR, Papadimitriou A, Silva KC, Amancio VH, Mendonça JN, Lopes NP, de Faria JB, de Faria JM. Polyphenol-enriched cocoa protects the diabetic retina from glial reaction through the sirtuin pathway. J Nutr Biochem. 2015;26(1):64-74.

57. Yanagisawa S, Papaioannou Al, Papaporfyriou A, Baker JR, Vuppusetty C, Loukides S, Barnes PJ, Ito K. Decreased serum sirtuin-1 in COPD. Chest. 2017; 152(2):343-52.

58. Bo S, Togliatto G, Gambino R, Ponzo V, Lombardo G, Rosato R, Cassader M, Brizzi MF. Impact of sirtuin-1 expression on H3K56 acetylation and oxidative stress: a double-blind randomized controlled trial with resveratrol supplementation. Acta diabetologica. 2018:55(4):331-40.

59. Aboelnaga SM. Effect of some levels of cardamom, clove and anise on hepatotoxicity in rats caused by CCL4. World Appl Sci J. 2015;33(6):854-65.

60. Rahman MM, Alam MN, Ulla A, Sumi FA, Subhan N, Khan T, Sikder B, Hossain $\mathrm{H}$, Reza HM, Alam MA. Cardamom powder supplementation prevents obesity, improves glucose intolerance, inflammation and oxidative stress in liver of high carbohydrate high fat diet induced obese rats. Lipids Health Dis. 2017;16(1):151.

61. Azimi P, Ghiasvand R, Feizi A, Hariri M, Abbasi B. Effects of cinnamon, cardamom, saffron, and ginger consumption on markers of glycemic control, lipid profile, oxidative stress, and inflammation in type 2 diabetes patients. Rev Diabet Stud. 2014;11(3):258.

62. Vaidya A, Rathod M. An in vitro study of the immunomodulatory effects of Piper nigrum (black pepper) and Elettaria cardamomum (cardamom) extracts using a murine macrophage cell line. AIJRFANS. 2014;8:18-27.

63. Majdalawieh AF, Carr RI. In vitro investigation of the potential immunomodulatory and anti-cancer activities of black pepper (Piper nigrum) and cardamom (Elettaria cardamomum). J Med Food. 2010; 13(2):371-81.

64. Radomska-Leśniewska DM, Skopiński P, Niemcewicz M, Zdanowski R, Lewicki S, Kocik J, Skopińska-Różewska E, Stankiewicz W. The effect of antiinflammatory and antimicrobial herbal remedy PADMA 28 on immunological angiogenesis and granulocytes activity in mice. Mediators Inflamm. 2013;2013:853475.

65. Kandikattu HK, Rachitha P, Jayashree GV, Krupashree K, Sukhith M, Majid A, Amruta N, Khanum F. Anti-inflammatory and anti-oxidant effects of Cardamom (Elettaria repens (Sonn.) Baill) and its phytochemical analysis by 4D GCXGC TOF-MS. Biomed Pharmacother. 2017:91:191-201.

66. Elguindy NM, Yacout GA, El Azab EF, Maghraby HK. Chemoprotective Effect of Elettaria cardamomum against Chemically induced Hepatocellular Carcinoma in Rats by Inhibiting NF-KB, Oxidative Stress, and Activity of Ornithine Decarboxylase. S Afr J Bot. 2016;105:251-8.

67. Darwish MM, Ash AEA. Role of cardamom (Elettaria cardamomum) in ameliorating radiation induced oxidative stress in rats. Arab J Nucl Sci Appl. 2013;46(1):232-9

68. Asimi OA, Sahu NP. Effect of Antioxidant Rich Spices, Clove and Cardamom Extracts on the Metabolic Enzyme Activity of Labeo rohita. J Fish Livest Prod. 2016;1:1-6.

69. Aboubakr M, Abdelazem AM. Hepatoprotective effect of aqueous extract cardamom against gentamicin induced hepatic damage in rats. Int J Basic Appl Sci. 2016;5(1):1.

70. Ghane Z, Vazini H, Pirestani M. Protective Effect of Hydroalcoholic Extract of Elettaria cardamomum L. Fruits on Serum Levels of Liver Enzymes and Morphpological Changes in Lead Induced Male Rats. J Mazandaran Univ Med Sci. 2016:26(142):1-3.

71. Bhaswant M, Poudyal H, Mathai ML, Ward LC, Mouatt P, Brown L. Green and black cardamom in a diet-induced rat model of metabolic syndrome. Nutrients. 2015;7(9):7691-707

72. Kazemi S, Yaghooblou F, Siassi F, Rahimi AF, Ghavipour M, Koohdani F Sotoudeh G. Cardamom supplementation improves inflammatory and oxidative stress biomarkers in hyperlipidemic, overweight, and obese prediabetic women: a randomized double-blind clinical trial. J Sci Food Agric. 2017:97(15):5296-301.
73. Badkook MM, Shrourou RM. Arabic coffee with two doses of cardamom: effects on health biomarkers in healthy women. Int J Nutr Food Sci. 2013; 2(6):280-6. https://doi.org/10.11648/j.ijnfs.20130206.13.

74. Bhattacharjee $B$, Chatterjee J. Identification of proapoptopic, antiinflammatory, anti-proliferative, anti-invasive and anti-angiogenic targets of essential oils in cardamom by dual reverse virtual screening and binding pose analysis. Asian Pac J Cancer Prev. 2013;14(6):3735-42.

75. Islam M, Alam F, Solayman M, Khalil M, Kamal MA, Gan SH. Dietary phytochemicals: natural swords combating inflammation and oxidationmediated degenerative diseases. Oxidative Med Cell Longev. 2016;2016 https://doi.org/10.1155/2016/5137431

76. Yashin A, Yashin Y, Xia X, Nemzer B. Antioxidant activity of spices and their impact on human health: A Review. Antioxidants. 2017;6(3):70. https://doi. org/10.3390/antiox6030070.

77. Torre E. Molecular signaling mechanisms behind polyphenol-induced bone anabolism. Phytochem Rev. 2017;16(6):1183-226.

78. Suen J, Thomas J, Kranz A, Vun S, Miller M. Effect of Flavonoids on Oxidative Stress and Inflammation in Adults at Risk of Cardiovascular Disease: A Systematic Review. Healthcare (Basel, Switzerland). 2016;4(3):69. https://doi. org/10.3390/healthcare4030069.

79. González R, Ballester I, López-Posadas R, Suárez MD, Zarzuelo A, MartinezAugustin O, Medina FS. Effects of flavonoids and other polyphenols on inflammation. Crit Rev Food Sci Nutr. 2011;51(4):331-62.

80. Hussain T, Tan B, Yin Y, Blachier F, Tossou MC, Rahu N. Oxidative stress and inflammation: what polyphenols can do for us?. Oxidative medicine and cellular longevity. 2016;2016. Article ID: 7432797, 9 pages. https://doi.org/10. $1155 / 2016 / 7432797$

81. Natsume M. Polyphenols: inflammation. Curr Pharm Des. 2017;24(2):191202. https://doi.org/10.2174/1381612823666171109104141.

82. Upadhyay S, Dixit M. Role of polyphenols and other phytochemicals on molecular signaling. Oxid Med Cell longev. 2015;2015. Article ID: 504253, 15 pages https://doi.org/10.1155/2015/504253

83. Ho SC, Chang PW. Inhibitory effects of several spices on inflammation caused by advanced glycation endproducts. Am J Plant Sci. 2012;3(07):9951002. https://doi.org/10.4236/ajps.2012.327118

84. Pandey KB, Rizvi SI. Current understanding of dietary polyphenols and their role in health and disease. Curr Nutr Food Sci. 2009:5(4):249-63.

85. Winarsi H, Yuniaty A, Nuraeni I. Improvement of Antioxidant and Immune Status of Atherosclerotic Rats Adrenaline and Egg-Yolks-Induced Using Cardamom-Rhizome-Ethanolic-Extract: An Initial Study of Functional Food. Agric Agric Sci Procedia. 2016;9:264-70.

86. Aggarwal BB, Van Kuiken ME, lyer LH, Harikumar KB, Sung B. Molecular targets of nutraceuticals derived from dietary spices: potential role in suppression of inflammation and tumorigenesis. Exp Biol Med. 2009:234(8):825-49.

87. Das I, Acharya A, Berry DL, Sen S, Williams E, Permaul E, Sengupta A, Bhattacharya S, Saha T. Antioxidative effects of the spice cardamom against non-melanoma skin cancer by modulating nuclear factor erythroid-2-related factor 2 and NF-KB signalling pathways. Br J Nutr. 2012;108(6):984-97.

88. Han X, Parker TL. Cardamom (Elettaria cardamomum) essential oil significantly inhibits vascular cell adhesion molecule 1 and impacts genome-wide gene expression in human dermal fibroblasts. Cogent Med. 2017;4(1):1308066

89. Al-Othman AM, Ahmad F, Al-Orf S, Al-Murshed KS, Arif Z. Effect of dietary supplementation of Ellataria cardamomum and Nigella sativa on the toxicity of rancid corn oil in Rats. Int J Pharmacol. 2006:2(1):60-5.

90. Sadeek EA, El-Razek FH. The chemo-protective effect of turmeric, chili, cloves and cardamom on correcting iron overload-induced liver injury, oxidative stress and serum lipid profile in rat models. J Am Sci. 2010;6(10):7.

91. Bhat GN, Nayak N, Vinodraj K, Chandralekha N, Mathai P, Cherian J. Comparison of the efficacy of cardamom (Elettaria cardamomum) with pioglitazone on dexamethasone-induced hepatic steatosis, dyslipidemia, and hyperglycemia in albino rats. J Adv Pharm Technol Res. 2015 Jul;6(3):136.

92. Hamzaa RG, Osman NN. Using of coffee and cardamom mixture to ameliorate oxidative stress induced in $\gamma$-irradiated rats. Biochem Anal Biochem. 2012;1(113):2161-1009. 